\title{
Mifepristone and misoprostol in pregnancy termination in hyperthyroid patients
}

\author{
Shyam Sunder Sud ${ }^{1}$, Mini Bhatnagar ${ }^{2}$, Nishi Sud $^{3}$ \\ ${ }^{1}$ Professor, Department of Obstetrics \& Gynaecology, M.M Medical College, Ambala, Haryana, India \\ ${ }^{2}$ Associate Professor, Department of Medicine, M.M Medical College, Ambala, Haryana, India \\ ${ }^{3}$ Assistant Professor, Department of Obstetrics \& Gynaecology, I.G.M.C, Shimla, Himachal Pradesh, India
}

Received: 1 July 2014

Accepted: 13 July 2014

\section{*Correspondence:}

Dr. Shyam Sunder Sud,

E-mail: drshyamsud2000@yahoo.co.in

(C) 2014 Sud SS et al. This is an open-access article distributed under the terms of the Creative Commons Attribution Non-Commercial License, which permits unrestricted non-commercial use, distribution, and reproduction in any medium, provided the original work is properly cited.

\begin{abstract}
Incidence of clinical hyperthyroidism in pregnant patients has been reported as $0.25-2.8 \%$. They may be anxious and may not opt for surgical methods of medical termination. Medical termination of pregnancy by Mifepristone and Misoprostol is increasingly being used. We do not know the efficacy of this method in hyperthyroidism.
\end{abstract}

Keywords: Mifepristone, Misoprostol, Hyperthyroidism

\section{INTRODUCTION}

We know that pregnancy with hyperthyroidism is associated with many adverse effects like preeclampsia, heart failure, preterm delivery, growth restriction. ${ }^{4}$ Little is known about pregnancy termination in hyperthyroid patients, using, mifepristone and misoprostol. Here we report 2 cases of hyperthyroidism undergoing pregnancy termination with these two agents.

\section{CASE REPORT}

\section{Case 1}

35 years old P2002 with 2 previous LSCS with 6 weeks of pregnancy came for medical termination of pregnancy. On examination, there was no examphalos, no pallor or icterus. Thyroid was not enlarged. Her pulse rate was $104 / \mathrm{mt}$ regular, BP was $150 / 100$. CVS examination did not reveal any abnormal heart sounds. On haematological examination haemoglobin was $10.9 \mathrm{gm} \%$, blood group was $\mathrm{B}+$. Her haemoglobin was $10.8 \mathrm{gm} \%$. Her RFT was done as she was hypertensive. Urea was 32 ; creatinine was $1 \mathrm{mg} / \mathrm{dl}$. She ultrasound was done which revealed intrauterine pregnancy of 6 weeks with yolk sac .She was anxiousand did not want surgery for pregnancy termination. She opted for medical method of pregnancy termination with mifepristone and misoprostol. She was given $200 \mathrm{mg}$ of mifepristone and after 48 hour 800 microgram of misoprostol was inserted vaginally. She did not have any vaginal bleeding. Since she was very apprehensive and adamant on not having any surgical procedure, we tried again with $600 \mathrm{mg}$ of mifepristone and 48 hours later 800 microgram misoprostol vaginally. There was no vaginal bleeding. She was advised thyroid function test. Her TSH was $0.04, \mathrm{~T}_{3}, \mathrm{~T}_{4}$ were increased. She was put on neomarcazole $5 \mathrm{mg}$ tds. Her TFT was repeated after 2 weeks and her TSH was 0.1. Her dose was increased to $40 \mathrm{mg} / \mathrm{day}$. After 1 week her TSH was 0.76 and free T4 was normal. By this time her pregnancy was 11 weeks. She was given $600 \mathrm{mg}$ of mifepristone and 800 microgram of misoprostol virginally. She had vaginal bleeding and completeness of M.T.P was proven after 1 week by ultrasound.

\section{Case 2}

36 years p4004 came to out-patient department with pregnancy of 6 weeks 4 days. She wanted pregnancy termination. On taking history, she revealed that her thyroid was enlarged for last 2 years. She was advised neomarcazole $30 \mathrm{mg}$ per day, which she had been taking 
irregularly. She was anxious, pulse rate was 110/mt, BP was 130/90. She had exampthalos. Her thyroid was enlarged irregularly. She underwent an ultrasound examination, which revealed intrauterine pregnancy of 5 weeks with yolk sac. Her TSH was 0.2 , free $\mathrm{T}_{4}$ was increased. She opted for medical method. She was given $600 \mathrm{mg}$ of mifepristone orally after 72 hours 800 microgram Misoprostol was inserted vaginally. She had mild vaginal bleeding. After 1 week her ultrasound revealed 7 weeks pregnancy with FCA +. Since she was insistent for not undergoing surgical method. We increased the dose of neomarcazole to $40 \mathrm{mg}$ per day and advised her to be regular in this treatment. She was called after 10 days. Her TFT was done and TSH was 0.48 Free $\mathrm{T}_{4}$ was in normal range. She was again given $600 \mathrm{mg}$ of mifepristone and 48 later vaginal 800 microgram of misoprostol. She was called after 1 week. She revealed that she had good amount of vaginal bleeding and ultrasound revealed absence of foetus.

\section{DISCUSSION}

Hyperthyroid patients do become pregnant. Incidence of hyperthyroidism in infertile patients is $4.2 \%{ }^{5}$ Symptomatic hyperthyroidism complicates 1 in 1000 to 2000 pregnancies $^{1}$ to $2.8 \%{ }^{2}$ of Pregnancies. Because normal pregnancy stimulates similar clinical findings to similar to thyroxin excess, mild thyrotoxicosis may be difficult to diagnose. Suggestive finding include tachycardia that exceeds that usually seen in normal pregnancy, thyromegaly, exophthalmos and failure to gain weight despite adequate food intake. ${ }^{4}$ Tachycardia was seen in both of our patients. One patient had exophthlos. Laboratory diagnosis is by depressed TSH and elevated serum free $\mathrm{T}_{4}{ }^{4}$ These findings were seen in both of our patients. There is high prevalence of anxiety and mood disorder in women with hyperthyroidism. ${ }^{3}$ Both of our cases were anxious and very reluctant to undergo surgical evacuation, in spite of failure of initial medical method of termination.

There is no literature available regarding efficacy of pregnancy termination in these patients with mifepristone and misoprostol. In a euthyroid patients, the regimens consisting of mifepristone and misoprostol in home based medical abortion is safe and effective. ${ }^{5}$ Clinical trials in United States, Canada and Turkey report complete abortion rate from $91 \%-100 \% .^{6-9}$ Hyperthyroidism in pregnancy is associated with low birth weight, intrauterine growth retardation, still birth, thyroid storm and maternal congestive heart failure. During early pregnancy symptoms of hyperthyroidism may worsen as HCG also has TSH like action. ${ }^{4}$

In general population the failure rate of mifepristone misoprostol is 0 to $9 \% .^{6-9} \mathrm{We}$ were not able to induce medical abortion in both cases of uncontrolled hyperthyroidism. More ever as soon as the hyperthyroidism is under control both of these cases were successful in having medical abortion with Mifepristone and misoprostol. In patients who are not successful in having medical abortion with above regime, it may be advisable to get thyroid function tests.

\section{Funding: No funding sources \\ Conflict of interest: None declared \\ Ethical approval: Not required}

\section{REFERENCES}

1. Casey BM, Leveno KJ. Thyroid disease in pregnancy. Obstet Gynaecol. 2006;108:1283.

2. Necetibumus, Isikustamer. Thyroid disease in pregnancy. Pak J Med Sci. 2013;29(5):1187-92.

3. Buneuicius R, Velickience D, Prage AJ. Mood and anxiety disorder in women with treated hyperthyroidism. Jr Hosp Psychiatry. 2005:27(2):133-9.

4. Mestman JH. Hyperthyroidism in pregnancy. Clin Obstet Gynaecol. 1997:40(1):45-69.

5. Rijal B, Shretha R, Jha B. Association of thyroid dysfunction among infertile women. Nepal Med Coll J. 2011;13(4):247-9.

6. Thoai D. Ngo, Min Hae Park, Haleena Shakur. Comparative effectiveness, safety and acceptability of medical abortion at home and in clinic: a systematic review. Bull WHO. 2011;89:360-70.

7. Creinin MD, Fox MC, Tear S, Chen A, Study Trial Group. A randomized comparison of Misoprostol6-8 hours versus 24 hours after mifepristone for abortion. Obstet Gynaecol. 2004;103:851-9.

8. Shannon C, Wiebe E, Jacot F. Regimens of misoprostol with mifepristone for early medical abortion: a randomized trial. BJOG. 2006;113:621-8.

9. Akin A, Blum J, Ozalp S, Onderoglu L. Results and lessons learned from a small medical abortion clinical study in Turkey. Contraception. 2004;70:401-6.

DOI: $10.5455 / 2320-1770$. ijrcog20140945

Cite this article as: Sud SS, Bhatnagar M, Sud N. Mifepristone and misoprostol in pregnancy termination in hyperthyroid patients. Int J Reprod Contracept Obstet Gynecol 2014;3:816-7. 